\title{
PELATIHAN PEMBUATAN PUPUK KOMPOS DI PERUM. BUMI TUNGGULWULUNG INDAH KOTA MALANG
}

\author{
Sumiadji ${ }^{1}$, Futuh $\mathrm{H}^{2}$, Basuki $\mathbf{R}^{3}$, Endah $\mathrm{S}^{4}$, Edi $\mathbf{W}^{5}$ \\ 1,2,3,4,5 Jurusan Akuntansi, Politeknik Negeri Malang \\ e-mail: ${ }^{1}$ sumiadjimalang@gmail.com
}

\begin{abstract}
Abstrak
Kegiatan PkM ini dilakukan untuk mengatasi permasalahan sampah yang dihadapi warga perum. Bumi Tunggulwulung Indah Lowokwaru Malang (BTWI) terutama berupa sampah daun dari pohon taman di perumahan. Terjadi penumpukan sampah dikarenakan sampah tidak secara rutin diangkut ke tempat penampungan sementara (TPS) dengan banyak sebab seperti faktor cuaca, tukang dan alat gerobak angkut atau kondisi volume sampah di TPS yang penuh. Khusus untuk sampah daun akan dibuat pupuk kompos kemudian dikemas dan dijual. Metode yang diterapkan dalam kegiatan PKM adalah penyuluhan, pelatihan dan pemantauan (monitoring). Penyuluhan pemberian materi teoritis tentang cara-cara pengelolaan dan pengolahan sampah. Pelatihan sebagai bentuk implementasi praktis dengan membuat pupuk kompos yang benar, efektif dan efisien sehungga memiliki nilai ekonomis. Pada tahap akhir dilakukan pemantauan hasil kegiatan pengabdian kepada masyarakat. Hasil kegiatan PkM menjadi salah satu solusi mengatasi masalah sampah menjadi produk bernilai ekonomis.
\end{abstract}

Kata kunci-perumahan bumi tunggulwung indah, sampah, pupuk kompos

\section{PENDAHULUAN}

$\mathrm{T}$ erdapat permasalahan yang dihadapi warga perumahan BTWI yaitu sering menumpuknya sampah. Akhir-akhir ini terdapat permasalahan yang berulang terkait dengan sampah. Permsalahan dapat diidentifikasi sebagai berikut:

1. Volume sampah di lingkungan BTWI cukup besar, selain sumber sampah dari rumah tangga juga sampah-sampah daun atau sampah kering dari pohon yang ada di sekitar rumah warga dan pohon-pohon di area taman. Volume sampah kering kurang lebih 50\% dari sampah rumah tangga.

2. Masalah pengangkutan sampah sering terkendala faktor cuaca, alat angkut, sumberdaya manusia pengangkut. Akibat keterlambatan pengangkutan sampah menyebabkan sampah menumpuk dan menimbulkan polusi yang berdampak juga bagi kesehatan masyarakat sekitar.
3. Penumpukan dan penuhnya volume sampah di Tempat Penampungan Sementara (TPS) Tunggulwulung.

Analisis situasi terhadap khalayak sasaran dapat disimpulkan adanya satu peluang di masyarakat khususnya perumahan BTWI melalui kegiatan pengabdian masyarakat untuk turut berkontribusi memecahkan masalah sampah di perum BTWI. Masalah yang ada dapat dirumuskan yaitu bagaimana mengelola sampah kering di lingkungan atau wilayah perumahan BTWI agar dapat menjadi pupuk kompos yang bernilai ekonomis.

\section{TARGET DAN LUARAN}

Sampah merupakan masalah besar, khususnya di kota-kota besar tidak terkecuali di Kota Malang. Penyebab masalah sampah umumnya muncul dari keterbatasan tempat penampungan sementara (TPS), tempat penampungan akhir (TPA) dan keterbatasan 
teknologi pengolahan sampah yang diterapkan. Tidak kalah penting adalah pengetahuan yang rendah tentang sampah dan budaya masyarakat yang cenderung membuang sampah sembarangan.

Indonesia menjadi negara kedua penghasil sampah terbanyak di dunia, setelah China. Pada 2019 Indonesia akan menghasilkan sampah sekitar 66-67 juta ton atau meningkat tiga juta ton dari tahun-tahun sebelumnya yang mencapai 64 juta ton (republika, 17 Juli 2019). Menurut data Kementrian Lingkungan Hidup dan Kehutanan, bahwa Indonesia memproduksi sampah hingga 65 juta ton pada 2016 tahun lalu. Jumlah sekarang naik 1 juta ton dari sebelumnya. Berdasarkan laporan Menteri Lingkungan Hidup dan Kehutanan Siti Nurbaya mengatakan sampah yang dihasilkan berdominan sampah organic yang mencapai sekitar 60 persen dan sampah plastik yang mencapai 15 persen dari total timbunan sampah, terutama di daerah perkotaan (Kompasiana, 23 April 2019). Sedangkan di Kota Malang produksi sampah menembus jumlah 500-600 ton/hari (surabaya.bisnis, 29

Juni 2019).

Menurut Wikipedia, jenis sampah dibedakan beberapa jenis yaitu berdasarkan sumbernya, sifatnya dan bentuknya. Jenis sampah berdasarkan sumbernya terdiri sampah alam, sampah manusia, sampah konsumsi, sampah nuklir, sampah industri dan sampah pertambangan. Jenis sampah berdasarkan sifatnya terdiri dari sampah organik (dapat diurai atau degradable) dan sampah anorganik (tidak terurai atau undegradable). Jenis sampah berdasarkan bentuknya terdiri dari sampah padat dan sampah cair.

Metode pengelolaan sampah berbedabeda tergantung banyak hal, di antaranya tipe zat sampah, tanah yang digunakan untuk mengolah dan ketersediaan area. Metodemetode tersebut antara lain:

\section{Vermi Compost}

Vermi Compost atau Kompos Cacing adalah pupuk yang berasal dari kotoran cacing (vermics). Pupuk ini dibuat dengan memelihara cacing dalam tumpukan sampah organik hingga cacing tersebut berkembang biak di dalamnya dan menguraikan sampah organik dan menghasilkan kotoran.

2. Biogas

Biogas merupakan gas yang dihasilkan oleh aktivitas anaerobik atau fermentasi dari bahan- bahan organik termasuk di antaranya; kotoran manusia dan hewan, limbah domestik (rumah tangga), sampah biodegradable atau setiap limbah organik yang biodegradable dalam kondisi anaerobik.

\section{Open Dumping}

Pembuangan sampah pada penimbunan darat termasuk mengubur-nya untuk membuang sampah, metode ini adalah metode paling populer di dunia. Penimbunan ini biasanya dilakukan di tanah yang tidak terpakai, lubang bekas pertambangan, atau lubang-lubang dalam.

4. Controlled Landfill

Controlled landfill adalah tempat pembuangan sampah yang dalam pemilihan lokasi maupun pengoperasiannya sudah mulai memperhatikan sayarat teknis (SNI) mengenai tempat pembuangan akhir sampah. Sistem Controlled Landfill merupakan tahap peningkatan dari metode Open Dumping.

\section{Sanitary Landfill}

Sanitary Landfill adalah sistem pengolahan sampah yang mengembangkan lahan cekungan dengan syarat tertentu meliputi jenis porositas tanah. Umumnya batuan landasan yang digunakan di lahan pembuangan adalah lempung atau pelapisan dengan geotekstil.

\section{Insenerator}

Insinerasi atau pembakaran sampah adalah teknologi pengolahan sampah yang melibatkan pembakaran bahan organik. Insinerasi dan pengolahan sampah bertemperatur tinggi lainnya didefinisikan sebagai pengolahan termal. Insinerasi material sampah mengubah sampah menjadi abu, gas sisa hasil pembakaran, partikulat, dan panas. 
Dari beberapa metode pengolahan sampah metode Vermi Compost atau Kompos Cacing merupakan metode yang cocok untuk mengatasi masalah sampah di perumahan BTWI, yang bermanfaat karena mampu diubah menjadi pupuk kompos yang dapat menyuburkan tanaman. Target pada kegiatan pengabdian ini adalah:

\section{Target Khalayak Sasaran}

Khalayak sasaran sebagai mitra kegiatan pengabdian adalah warga BTWI yang terdiri dari perwakilan pengurus Rukun Tetangga (RT), perwakilan / penggerak PKK, perwakilan dari komunitas "kampung enterprener" dan pengurus Koperasi Sinergi yang dikoordinir oleh pengurus RT - Bidang Lingkungan dan Kebersihan. Jumlah anggota mitra yang berpartisipasi.dalam kegiatan pengabdian masyarakat sebanyak 15 orang.

\section{Target Kegiatan}

Target dari kegiatan bagi warga BTWI adalah terselesaikannya masalh sampah di lingkungan perumahan BTWI melalui pengolahan sampah menjadi produk pupuk kompos yang bernilai ekonomis.

Luaran dari kegiatan PKM adalah berupa metode dan produk. Metode merupakan cara yang diterapkan untuk memecahkan masalah. Produk merupakan sasaran akhir dari penerapan metode berupa pupuk kompos.

\section{METODE}

Pelaksanaan kegiatan PKM meliputi 3 (tiga) metode yaitu penyuluhan, pelatihan dan pemantauan hasil (monitoring). Tim pelaksana menjadi tim inti untuk masing-masing kegiatan, mengikuti jadwal kesepakatan dengan mitra / khalayak sasaran kegiatan. Teknis pelaksanaan kegiatan pengabdian kepada masyarakat dibagi menjadi:

\section{Penyuluhan}

Pemberian materi melalui ceramah dimana pemateri memberikan penjelasan tentang topik pengelolaan dan pengolahan sampah. Bahan materi yang akan dibahas sebelumnya sudah diberikan kepada peserta pelatihan agar pelaksanaan lebih efektif.
Mengajak diskusi dan tanya jawab peserta penyuluhan agar pelaksanaan penyuluhan lebih efektif dan mudah memahami dalam praktek pelatihan.

\section{Pelatihan}

Memberikan materi praktik pembuatan pupuk kompos mulai dari persiapan sampai dengan pengepakan kepada komunitas mitra.

\section{Pemantauan}

Pemantauan hasil praktik pembuatan pupuk kompos mulai dari persiapan sampai dengan pengepakan, yang dilakukan oleh komunitas mitra.

Mitra kegiatan adalah warga BTWI yang tergabung dalam komunitas "kampung enterprener" yang dikoordinir khususnya yang berkaitan dengan dengan kegiatan PkM adalah bidang kebersihan. Jumlah anggota mitra kurang lebih 10 sampai dengan 15 orang yang berpartisipasi dalam kegiatan penyuluhan dan pelatihan. Luaran kegiatan $\mathrm{PkM}$ berupa produk pupuk kompos yang dikemas plastik dengan berat $5 \mathrm{~kg}$.

\section{KELAYAKAN PENGUSUL DAN MITRA}

\section{Kelayakan Pengusul}

Tim pengusul adalah para dosen dari Jurusan Akuntansi dibantu tenaga pendidikan dan mahasiswa. Bidang keahlian keilmuan tim pengusul dosen adalah bidang akuntansi, keuangan dan bahasa Inggris, namun terdapat bidang keahlian lainnya yang mendukung pelaksanaa kegiatan pengabdian kepada masyarakat ini, khususnya dalam kegiatan pelatihan praktis.

\section{Kelayakan Mitra}

Mitra kegiatan ini adalah warga perumahan BTWI yang diwadahi dalam komunitas "Kampung Enterprener". Penanggungjawab mitra adalah salah satu penggerak ekonomi kreatif di Kota Malang. Bidang yang terkait dengan kegiatan $\mathrm{PkM}$ di tempat mitra adalah bidang kebersihan. Secara umum dalam lingkungan kampung enterprener didukung instrumen ekonomi yang bergerak di bidang jasa, perdagangan dan produksi termasuk unit usaha Koperasi Sinergi 


\section{HAL YANG DICAPAI}

Pelaksanaan kegiatan pengabdian dan hasil yang dicapai adalah sebagai berikut: Penyuluhan

Pemberian materi melalui ceramah dilakukan pada tanggal 26 Juli 2020. Pelaksanaan kegiatan mengalami perubahan jadwal karena pertimbangan kondisi pandemi Covid 19. Peserta kegiatan penyuluhan dibatasi menjadi sekitar 50\% dari target awal sebanyak 30 peserta yang cukup diwakili oleh perangkat pengurus RT, organisasi kemasyarakatan internal Koperasi Sinergi dan aktivis kelompok

PKK. Pelakasanaan menerapkan protokol kesehatan dengan menjaga jarak peserta, penggunaan masker dan/atau fieldface dan aktif mencuci tangan sesering mungkin. Tempat pelaksanaan penyuluhan dilakukan di selasar Masjid At-Taqwa perumahan BTWI. Penyuluhan memberikan pemahaman pengelolaan sampah dan pembuatan kompos.

\section{Pelatihan}

Tanggal 23 Agustus 2020 memberikan materi praktik dengan hasil berikut: Tersedia keranjang untuk penampungan sampah daun di beberapa titik strategis. Penyediaan tempat penjemuran sampah. Pengadaan alat giling sampah rakitan. Tersedia galian lubang untuk menanpung rajangan samapah

Luaran kegiatan PkM berupa produk pupuk kompos yang dikemas plastik dengan berat $5 \mathrm{~kg}$ dengan harga Rp3000,- / pak. Produk digunakan terutama untuk warga sendiri perumahan BTWI dan warga perumahan sekitar daerah Tunggulwulung.

\section{Pemantauan}

Pembuatan pupuk kompos dilakukan pada hari minggu, oleh beberapa warga. Pemantauan pembuatan pupuk kompos kering telah dilakukan sekali untuk memastikan implementasi program-program kegiatan pengabdian telah berjalan dengan baik. Pemantauan kegiatan kepada komunitas mitra dilakukan melalui kunjungan dan komunikasi melalui whatsapp.

\section{SIMPULAN DAN SARAN}

\subsection{Simpulan}

$\begin{array}{ccc}\text { Kegiatan } & \text { pengabdian } & \text { kepada } \\ \text { masyarakat tahap } & 1 \text { dengan } & \text { agenda }\end{array}$

penyampaian materi atau penyuluhan tentang pengelolaan sampah sudah dilaksanakan pada hari minggu tanggal 26 Juli 2020. Pelaksanaan PkM berupa implementasi praktis dilakukan pada hari minggu 23 Agustus 2020 dengan melakukan tahapan-tahapan dan menghasilkan peralatan pengolahan sampah dari hulu hingga hilir. Hasil berupa pupuk kompos dipergunakan oleh warga perumahan BTWI dan sekitarnya. Produk pupuk kompos menghasilkan pendapatan yang dimasukkan sebagai pendapatan koperasi yang dimiliki warga BTWI.

\subsection{Saran}

Kegiatan pengabdian telah memberikan solusi masalah pengolahan sampah kering (daun dari pohon-pohon). Ada peluang untuk memasarkan produk lebih profesional misalnya pengepakan dengan baik diberi cap serta dipasarkan menggunakan media sosial. Sampah yang tersisa untuk diangkut ke temapat TPS menjadi berkurang, tinggal sampah-sampah dapur atau sampah basah. Oleh karena itu disarankan warga BTWI ke depan dapat mengurangi sampah dengan mengolah sampah dapur agar sampah yang diangkut ke TPS menjadi berkurang siknifikan.

\section{DAFTAR PUSTAKA}

Badan Pusat Statistik, Malang Dalam

Angka 2018

http://www.kompasiana.com/niningkurnia/5cb ef26595760e2b081e54a4/sampah-menjadimasalah-lingkungan-di-indonesia? diakses tanggal 18 Januari 2020

https://surabaya.bisnis.com/read/20190626/ 531/93 8072/produksi-sampah-kotamalang- tembus-500-600-tonhari. Diakses tanggal 18 Januari 2020

https://g8penyuluhan2016.wordpress.com/ diakses tanggal 18 Januari 2020

https://id.wikipedia.org/wiki/Sampah?veacti on=edi t\&section=3. Diakses tanggal 19 Januari 2020

https://nasional.republika.co.id/berita/pus5ex3 68/sa mpah-indonesia-terusmeningkat-tiga- 
juta-ton-tiap-tahun. Diakses tanggal 18 Januari 2020 